\title{
Male reproductive patterns in hibernating bats
}

\author{
A. W. Gustafson \\ Department of Anatomy, Tufts University School of Medicine, 136 Harrison Avenue, Boston, \\ Massachusetts 02111, U.S.A.
}

Early reports on studies of reproduction in bats that hibernate (Families Vespertilionidae and Rhinolophidae) described various aspects of form, function, and periodicity in both males and females (e.g. Benecke, 1879; Eimer, 1879; Fries, 1879; Van Beneden, 1880; Robin, 1881; Vogt, 1881; Duval, 1895a, b; Rollinat \& Trouessart, 1895a, b, c, 1896, 1897; Rauther, 1903; Branca, 1904; Schoenfeld, 1904; Jordan, 1912; Retterer \& Neuville, 1913). Collectively, these accounts suggested that the reproductive events and patterns operative in hibernating bats were markedly different from those of other mammals. However, it was the extensive work of Courrier (1920, $1923 \mathrm{a}, \mathrm{b}, 1926 \mathrm{a}, \mathrm{b}, 1927)$ and that by Vignoli (1930) that clearly demonstrated the unusual reproductive cycles of male hibernating bats. These studies, as well as subsequent related investigations, have not only set hibernating male bats apart from their nonhibernating counterparts but also from other male mammals, hibernators or otherwise.

The annual reproductive cycles of all male bats that hibernate examined to date, both Nearctic and Palaearctic species, are characterized by an asynchronous, seasonal reactivation of the primary and secondary sexual organs. This asynchrony thus results in a marked temporal separation of certain reproductive functions and activities in these animals. In summary, primary reproductive function (spermatogenesis) occurs only during the summer or into the early fall. In contrast, secondary reproductive function and activity (maximally stimulated accessory organs, stored epididymal spermatozoa, libido and sexual congress) occur later during a mating period that for most species is interrupted, and therefore extended, by hibernation (see Table 1). This dissociation of reproductive functions and activities has been shown for the species indicated in Table 2. In addition, this dissociation can be inferred from studies of other bats for which more complete data are lacking: Eptesicus fuscus fuscus, western U.S.A. (Phillips, 1966); Myotis austroriparius (Rice, 1957); M. daubentoni (Herlant, 1967); M. keenii septentrionalis (Gustafson, 1975a); M. l. leibii (Gustafson, 1975a); M. mystacinus (Herlant, 1967); Pipistrellus abramus (Nakano, 1928); P. subflavus (Gustafson, 1975a); Plecotus auritus (Courrier, 1927; Stebbings, 1966); P. austriacus (Stebbings, 1966); Rhinolophus ferrumequinum korai (Oh, 1977); Vespertilio superans (Oh, 1977).

Undoubtedly, the seasonal 'peculiarities' of male reproductive periodicity in bats that hibernate are largely the result of physiological adaptations to a prolonged interval of hibernation (see Wimsatt, 1960, 1969; Krutzsch, 1979).

\section{Patterns of male cycles}

Male reproductive periodicity in hibernating Chiroptera can be divided into two general patterns based on the timing and duration of the principal events of the annual reproductive cycles in relation to hibernation (see Courrier, 1927; Wimsatt, 1960, 1969). Furthermore, each of these patterns corresponds respectively to one of two reproductive patterns shown by conspecific females (see Oxberry, 1979). The male patterns are identified by types in Table 1 and by species in Table 2. In the Type I pattern, the male reproductive cycles are interrupted annually by 


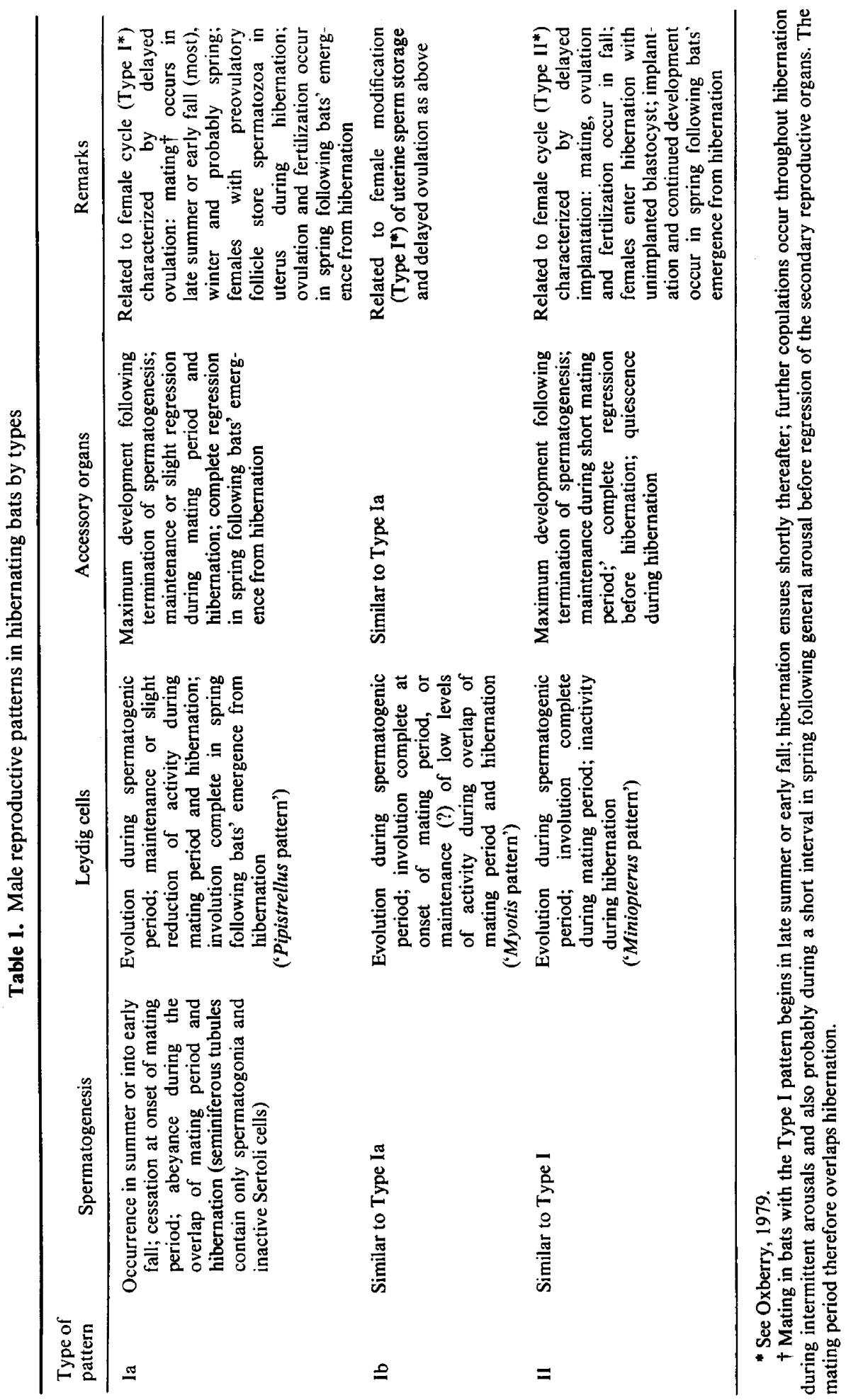


Table 2. Male reproductive patterns in hibernating bats by species

\begin{tabular}{|c|c|c|}
\hline $\begin{array}{l}\text { Type of } \\
\text { pattern }\end{array}$ & Species & References \\
\hline Ia & $\begin{array}{l}\text { Eptesicus serotinus } \\
\text { Nyctalus noctula } \\
\text { Pipistrellus hesperus } \\
\text { Pipistrellus pipistrellus } \\
\text { Rhinolophus ferrumequinum } \\
\text { Rhinolophus hipposideros }\end{array}$ & $\begin{array}{l}\text { Courrier (1923b, 1927) } \\
\text { Racey (1974) } \\
\text { Krutzsch (1975) } \\
\text { Courrier (1923a, b, 1926b, } \\
\text { 1927); Racey \& Tam (1974) } \\
\text { Courrier (1927); Vignoli (1930) } \\
\text { Courrier (1923b, 1927); Gaisler } \\
\quad \text { \& Titlbach (1964); Gaisler } \\
\text { (1966) }\end{array}$ \\
\hline Ib & $\begin{array}{l}\text { Eptesicus fuscus fuscus } \\
\quad \text { (eastern U.S.A.) } \\
\text { Myotis blythi oxygnathus } \\
\text { Myotis capaccinii } \\
\text { Myotis grisescens } \\
\text { Myotis l. lucifugus } \\
\text { Myotis myotis } \\
\text { Myotis velifer } \\
\text { Plecotus townsendii }\end{array}$ & $\begin{array}{l}\text { Christian (1956) } \\
\text { Koceva (1970) } \\
\text { Courrier (1927) } \\
\text { Miller (1939) } \\
\text { Miller (1939); Gustafson } \\
\quad(1975 \mathrm{a}, 1976) \\
\text { Courrier (1923b, 1927); Sluiter } \\
\quad(1961) \\
\text { Krutzsch (1961) } \\
\text { Pearson et al. }(1952)\end{array}$ \\
\hline II & Miniopterus schreibersii ${ }^{*}$ & Courrier $(1923 b, 1927)$ \\
\hline
\end{tabular}

hibernation so that secondary sexual activities extend into and throughout the period of dormancy; this pattern corresponds to the female pattern of delayed ovulation (see Table 1). In the Type II pattern, whose only known representative to date is Miniopterus, the male reproductive cycle does not overlap the period of dormancy because secondary sexual activities are completed before hibernation; this pattern corresponds to the female pattern of delayed implantation (see Table 1). The duration of the functional phases of one complete Type II male cycle is therefore shorter than that of any of the Type I male cycles, even though the spermatogenic periods for both types are similar in timing and duration. In addition, the two patterns differ with respect to the annual periodicity of the Leydig cells, although there are variations even within the males of Type I classification. Based on the studies cited in Table 2, three patterns of Leydig cell evolution seem to exist; these patterns are identified (see Table 1) as the 'Pipistrellus pattern', 'Myotis pattern' and 'Miniopterus pattern' according to the genus in which they were first described. However, in that the 'Pipistrellus' and 'Myotis patterns' have certain similarities (evidence is offered later) and both occur in species that have a singular female pattern, i.e. delayed ovulation, these Leydig cell patterns are considered in this summary as subsets of the general Type I male pattern (see Table 1). Nevertheless, the validity of this classification and the assignment of species to a particular Leydig cell pattern, although consistent with present data, will be verified only when more detailed studies using modern methods of analysis are applied to problems in bat reproduction.

Type I pattern is represented by both Old and New World species. However, the Type II pattern is represented only by European members of Miniopterus schreibersii. Although Australian miniopterines closely resemble this pattern of their northern temperate relative, the temporal separation of primary and secondary reproductive functions does not appear to be as pronounced (Dwyer, 1963a, b; Richardson, 1977). The Australian variances, which seem to be 
more closely related to the cycles of nonhibernating, tropical members of this genus, may be influenced by shorter and less severe hibernation periods.

As suggested by Table 1, the asynchronous nature of the male reproductive patterns is revealed and appreciated by dissecting the overall reproductive cycles into their component subcycles of the seminiferous epithelium, the interstitial (Leydig) cells and the accessory reproductive organs.

\section{Spermatogenesis}

As spermatogenesis in all species occurs only during summer or into early fall when the bats are most active (not hibernating), the seminiferous epithelium is at rest from the beginning of the mating period until the end of hibernation. During this interval, the seminiferous tubules are characterized by a prepubertal-like appearance in that they contain only spermatogonia and inactive Sertoli cells (see Pl. 2, Fig. 3).

Following the emergence of bats from their hibernacula in the spring, there is an annual reawakening of activity in the seminiferous epithelium which begins with a period of intense mitotic activity (spermatocytogenesis) that varies slightly in duration according to species. The resulting daughter cells of the overwintering spermatogonia fill and begin to expand the tubules. This proliferation of germinal stem cells accounts, in part, for the increase in testicular size observed at this time (see Pearson, Koford \& Pearson, 1952). In addition, Sertoli cells undergo concomitant hypertrophic changes (see Racey, 1974), a factor which contributes further to the expansion of the tubules. Soon thereafter, primary spermatocytes appear. The remainder of the summer or early fall is characterized primarily by the processes of meiosis (see Pl. 1, Fig. 1) and spermiogenesis. Although spermatocytogenesis continues, it does so to a lesser extent as evidenced by fewer spermatogonial mitotic figures. It is during this period that maximum tubular diameter and testicular size occur (see Text-fig. 1).

In late summer or early fall seminiferous activity subsides and spermatozoa pass into the excurrent ducts so that tubular diameter as well as testicular size diminishes (see Text-fig. 1). The results of the spermatogenic process thus become manifest in engorged epididymides in which the gametes are stored, primarily in the caudal portions, in anticipation of a short, ensuing mating period (Type II pattern) or an extended, ensuing mating period which overlaps hibernation (Type I pattern). In the latter case, any spermatozoa not utilized in the mating effort are not lost until the following spring. Therefore, the annual activity of the germinal epithelium occurs before mating takes place, and a resting, prepubertal-like condition prevails in the seminiferous tubules (Pl. 2, Fig. 3) throughout the periods of mating and/or hibernation. Storage of spermatozoa, however, occurs in the reproductive tracts of bats with the Type I pattern during the prolonged mating period (see Racey, 1979).

Although spermatogenesis is in abeyance throughout hibernation, a period that is refractory to the re-initiation of this process probably occurs only during the first half of hibernation.

\section{PLATE 1}

Fig. 1. Photomicrograph of a portion of the testis from the hibernating bat Myotis lucifugus lucifugus in late June. Seminiferous tubules (ST) contain mostly primary spermatocytes in early meiotic prophase. Interstitial regions are occupied by spongiocytic Leydig cells (LC) with numerous lipid droplets (arrows) of various diameters. Bar $=10 \mu \mathrm{m}$.

Fig. 2. Electron micrograph of a portion of a Leydig cell from Myotis l. lucifugus in late June. The appearance and distribution of organelles are typical of those in an active steroid-secreting cell. Cytoplasm contains a well developed smooth endoplasmic reticulum (SER), numerous lipid droplets (LD) and mitochondria with predominantly tubular cristae (single arrows), although lamellar cristae may also be present (double arrows). Bar $=1 \mu \mathrm{m}$. 
PLATE 1
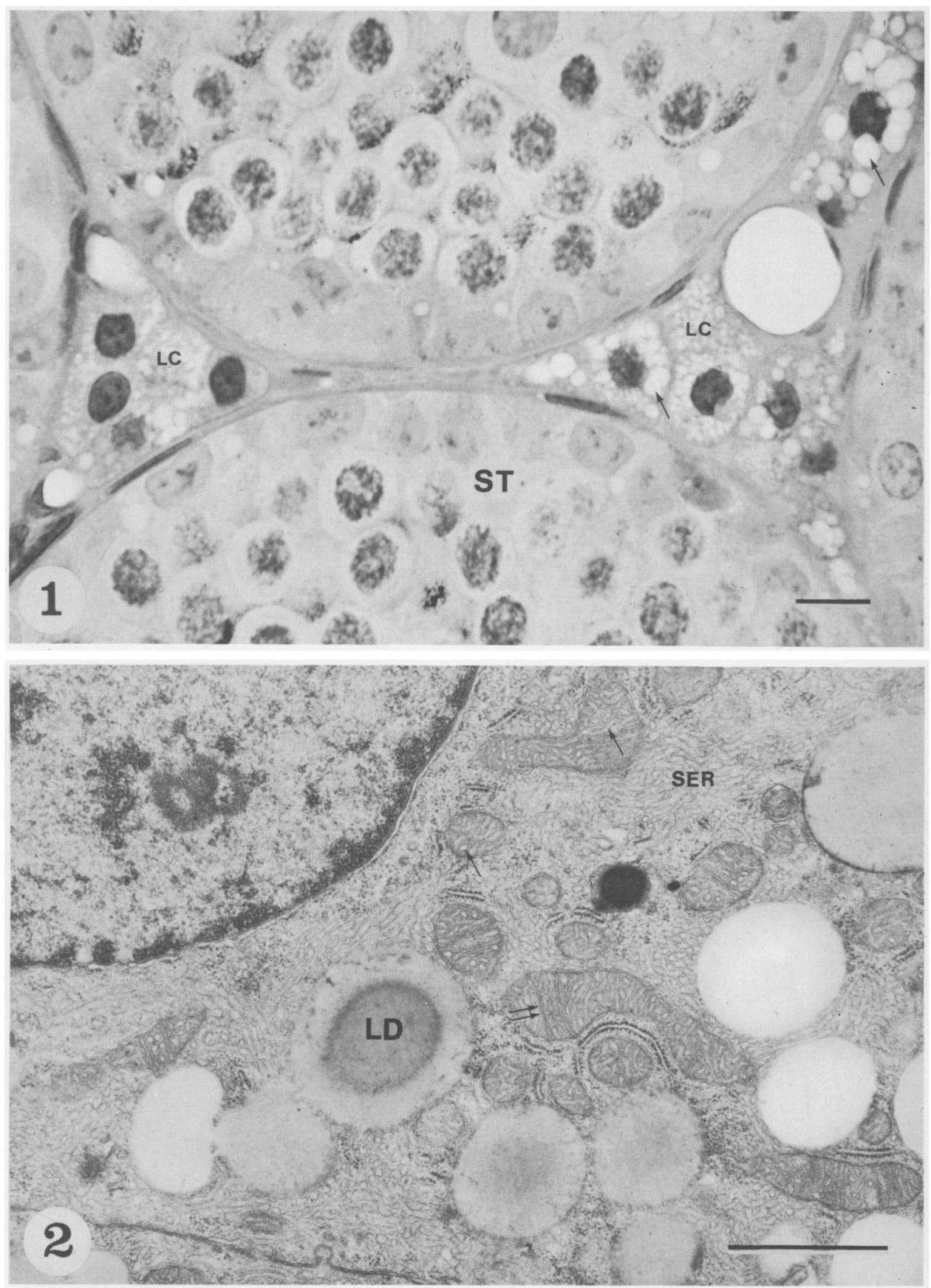

(Facing p. 320) 
PLATE 2
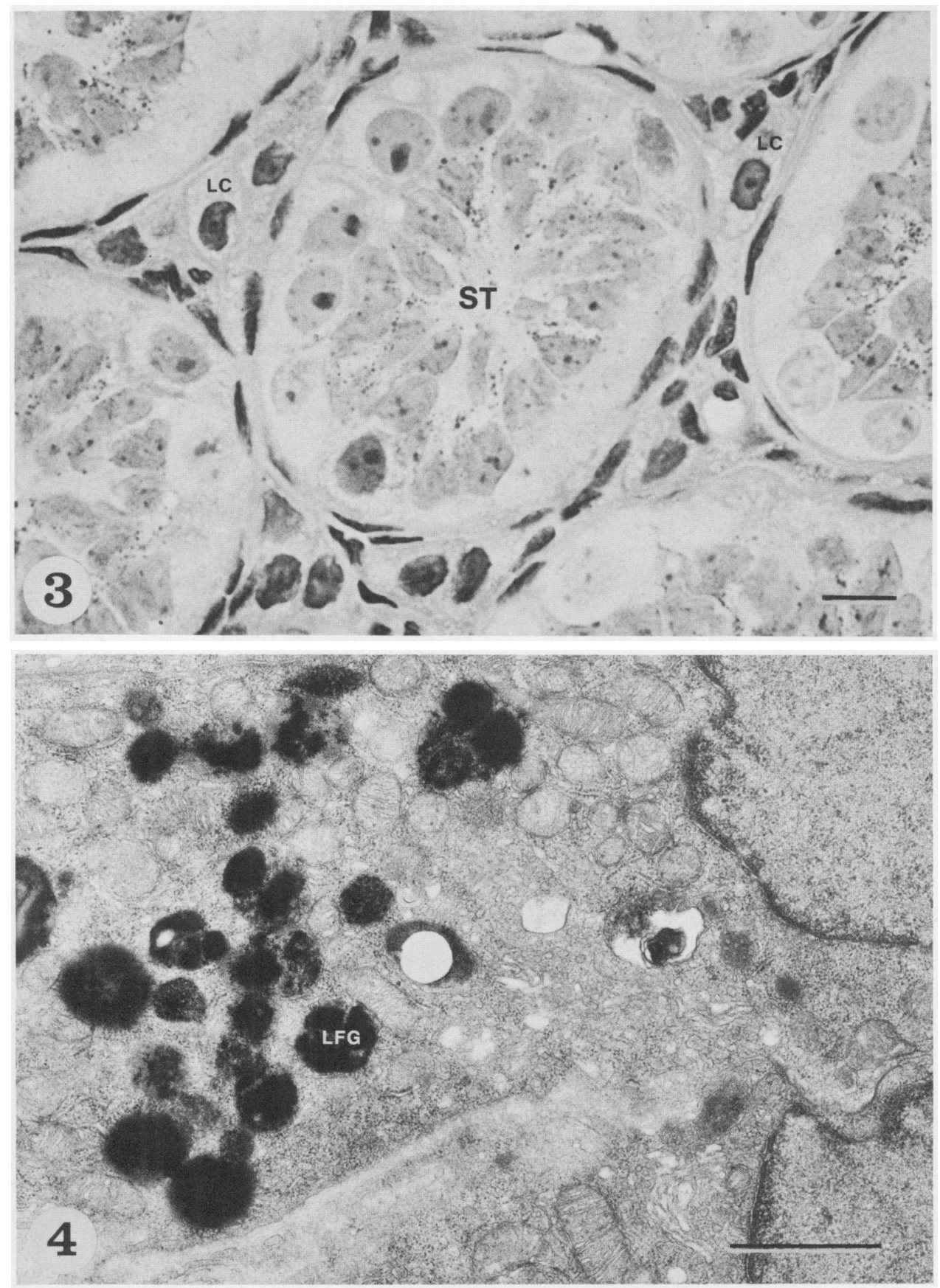
Evidence for this statement comes from at least two lines of observation on Type I species. First, if bats are artificially aroused during the first half of hibernation and maintained in the laboratory at elevated temperatures, the testes remain in a quiescent condition. However, if this experiment is conducted during the second half of hibernation, the testes increase in size due to spermatogenic re-initiation (A. W. Gustafson, unpublished observations on Myotis l. lucifugus). A similar response has also been noted in the European species Nyctalus noctula (Racey, 1974) and Pipistrellus pipistrellus (Racey \& Tam, 1974). Further, after 2 weeks of keeping bats at elevated temperatures during the second half of hibernation, $\Delta^{5}-3 \beta$-hydroxysteroid dehydrogenase can be histochemically demonstrated in the Sertoli cells although this steroid interconverting enzyme is absent from seminiferous tubules of normally hibernating bats (Gustafson, 1976) as well as from bats artificially aroused during the first half of hibernation (A. W. Gustafson, unpublished). Secondly, mitosis of spermatogonia has been observed in hibernating bats collected under
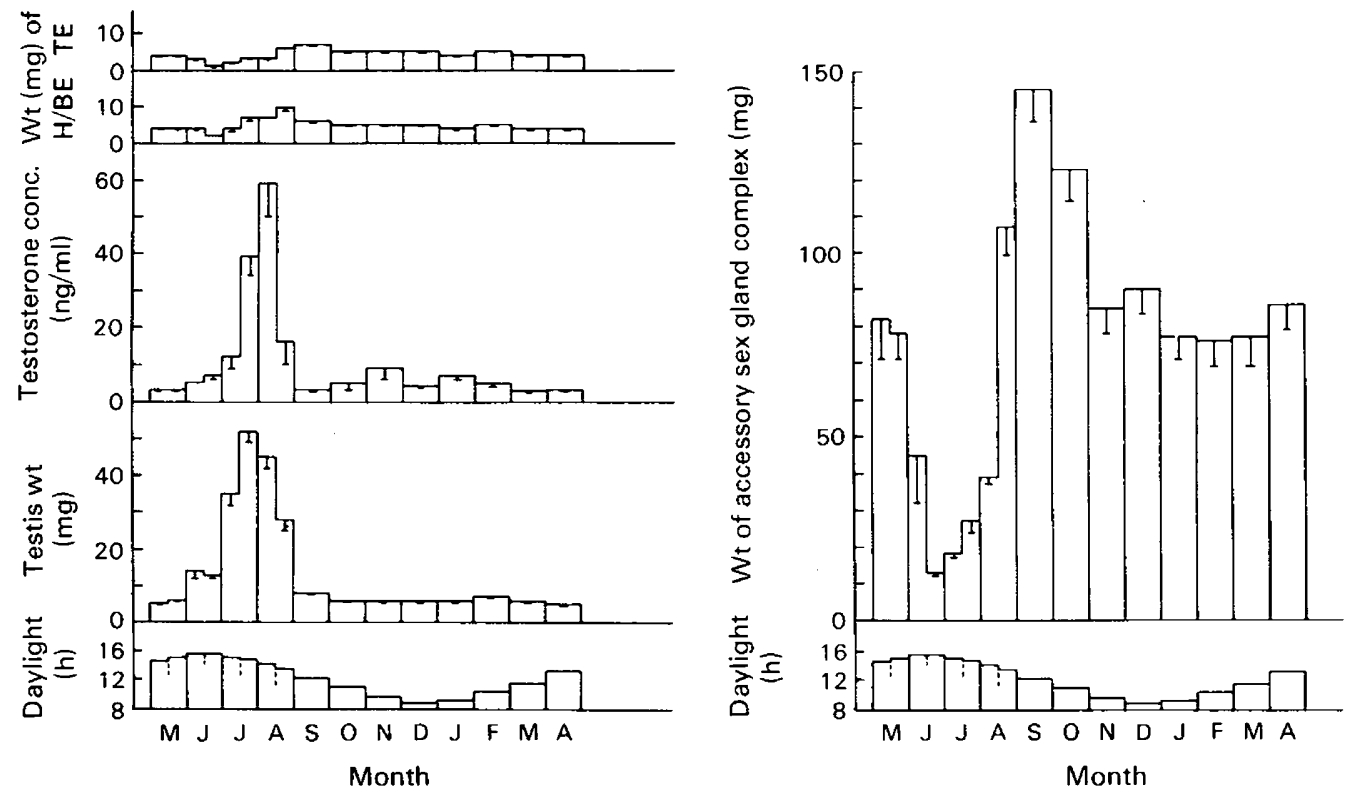

Text-fig. 1. Histogram showing reproductive organ weights and plasma testosterone values during a 'typical' annual reproductive cycle in Myotis l. lucifugus. Organ weights are mean \pm s.e.m. from 3 annual cycles; testosterone levels are mean \pm s.e.m. from 1 cycle. (Testosterone data taken from Gustafson \& Shemesh, 1976). H/BE, caput/corpus epididymidis; TE, cauda epididymidis.

\section{PLATE 2}

Fig. 3. Photomicrograph of a portion of the testis from Myotis l. lucifugus in mid-September. Spermatogenesis has ceased and seminiferous tubules (ST) have a prepubertal-like appearance in that they contain only basally located spermatogonia and inactive Sertoli cells. This condition is characteristic of testes during the mating period and hibernation. Interstitial regions contain involuting Leydig cells (LC). Compare with Fig. 1. Bar $=10 \mu \mathrm{m}$.

Fig. 4. Electron micrograph of portions of two Leydig cells from Myotis l. lucifugus in midSeptember. Involution is fully evident. Smooth endoplasmic reticulum is scarce; mitochondria contain mostly lamellar cristae; and lipofuscin pigment granules (LFG) are abundant. Compare with Fig. 2. bar $=1 \mu \mathrm{m}$. 
natural conditions during the second half of hibernation and these divisions increase in frequency as the period of spring arousal approaches (see Miller, 1939; Pearson et al., 1952; Gustafson, 1975a). Other evidence will be presented below.

In addition to routine histological examinations of the testis or measurements of seminiferous tubule diameters, testicular dimensions (Pearson et al., 1952; Kunz, 1973; Krutzsch, 1975) and testicular weight (Gaisler \& Titlbach, 1964; Racey, 1974; Racey \& Tam, 1974; Gustafson, 1975a) have been used as criteria for assessing annual changes in tubular activity of hibernating bats. Histological examination has repeatedly shown that maximal spermatogenic activity is associated with both maximal tubular diameter and maximal testicular weight (Racey, 1974; Racey \& Tam, 1974; Gustafson, 1975a). It would therefore seem that testicular weight is a convenient quantitative measure of general changes in annual spermatogenic activity (see Textfig. 1).

\section{Leydig cells}

Histology. Courrier (1923a, b, 1927) in a series of studies of the annual cycles in male hibernating bats was impressed by the fact that actively spermatogenic testes and inactive accessory organs could be observed simultaneously at one time of the year, whereas at another time the inverse could apparently be found. In examining the "diastematic" or "interstitial" gland (Leydig cells), he interpreted its histological cycle as having a functional phase that generally corresponded to that of the accessory organ cycle. He also suggested that the increased size of the Leydig cells observed in late summer and maintained during hibernation, more in some species but considerably less in others, was supportive of this interpretation. Courrier thus referred to a "spermato-diastematic dissociation" in describing the annual pattern of the spermatogenic and Leydig cell cycles. A marked departure from this 'Pipistrellus pattern' of Leydig cell activity was reported when the cycles of males of some North American species were first examined (Miller, 1939; Pearson et al., 1952; Krutzsch, 1961). In these studies, the observed changes in Leydig cell histology suggested that functional activity occurred during the summer or early fall in parallel with the period of spermatogenic activity ('Myotis pattern'). Histological observations of smaller cells during the rest of the year (compare Pl. 1, Fig. 1 and PI. 2, Fig. 3) also suggested that Leydig cells were involuted during mating and hibernation when the accessory organs were fully developed. In order to reconcile this apparent discrepancy, it has been suggested by several authors that the smaller cell may, in fact, be more active. The apparent exaggerated asynchrony of the spermatogenic and endocrine functions of the testis that occurs in certain bats ('Pipistrellus pattern') and, likewise, the apparent functional cycle of Leydig cells that does not coincide completely with the period of secondary sexual activity that occurs in others ('Myotis pattern') have been previously reviewed by Wimsatt $(1960,1969)$.

Histological examination by conventional methods has generally been the only assessment of annual variations in Leydig cells for the majority of bats studied (see Table 2 for references). As histological means alone are generally inadequate indicators of Leydig cell function, such analysis has probably led to misinterpretations of the precise nature and duration of Leydig cell activity in relation to other reproductive events. Indeed, some investigators have indicated that the Leydig cell morphology of bats does not change with season. Other methods for assessing Leydig cell activity have therefore been sought.

Fine structure. Correlative studies at the electron microscopic and biochemical levels have established the fine structural characteristics related to active steroid synthesis and secretion in Leydig cells for a wide variety of mammals (see reviews by Christensen \& Gillim, 1969; Christensen, 1975; Neaves, 1975, 1977). However, only one electron microscopic examination of Leydig cells in bats appears to have been made. In this study, Leydig cells of the North American species Myotis l. lucifugus (Type Ia pattern) were examined throughout the annual reproductive cycle (Gustafson, 1975a, 1976): cells possessed the machinery for androgen 
synthesis associated with active steroid-secreting cells only during the summer spermatogenic period.

In northeastern U.S.A. members of this species, hibernation extends from about late September/early October until late April/early May. After the bats emerged in spring, the Leydig cells in May were small and poorly developed. They contained mitochondria with predominantly lamellar cristae, scant profiles of rough endoplasmic reticulum, many free ribosomes or polysomes, a few lipid droplets, some lipofuscin pigment granules, and little or no smooth endoplasmic reticulum (SER). In June, however, these cells had undergone rapid renewal as the SER had proliferated to such a degree that it occupied most of the cytoplasm. The SER occurred as an anastomosing tubular network that is typical of the SER found in active steroid-secreting cells (see Christensen \& Gillim, 1969), and also as concentric, cisternal arrays around lipid droplets. Mitochondria were swollen and now possessed mostly tubular cristae, also a typical feature of these organelles in most other steroid-secreting cells (see Belt \& Pease, 1956). In addition, lipid droplets had increased in number, whereas lipofuscin pigment granules were generally absent. The proliferation of organelles, particularly the SER, caused a marked hypertrophy of the Leydig cells. In late June hypertrophied Leydig cells, with a spongiocytic appearance, and swollen lymphatic spaces characterized the interstitial regions (see Pl. 1, Fig. 1). A striking feature of Leydig cells at this time was their great abundance of lipid droplets which accounts for the spongiocytic appearance. The characteristic machinery of cells actively synthesizing steroids was still well represented (Pl. 1, Fig. 2). In mid-July there was a decrease in the number of lipid droplets, but the pattern of organelles appeared unchanged. In late July, the number of lipid droplets dramatically decreased. Furthermore, the extent of SER was reduced, a condition that apparently signals the deterioration of this organelle because some resultant lipofuscin pigment granules and myelin figures were present. This degradative process was fully evident during August because the SER was much less conspicuous and lipofuscin pigments, myelin figures, and various autophagic vacuoles were more common. At the beginning of mating in September, the cytoplasmic volume of Leydig cells was greatly reduced, compared to the hypertrophic condition of preceding months (see Pl. 2, Fig. 3). At this time, the once abundant SER was lacking and mitochondria possessed primarily lamellar cristae, although some tubular formations were still present (Pl. 2, Fig. 4). Some cells contained massive accumulations of lipofuscin and other products of intracellular digestion. This condition, more or less, also represented the appearance of Leydig cells during the ensuing hibernation period.

This study has suggested that, at least for Myotis $l$. lucifugus, maximal Leydig cell development in relation to apparent steroidogenic capability occurs during the summer spermatogenic period, whereas involution of these cells prevails during the mating and hibernation periods.

Histochemistry. Lipids and various enzymes in the testes of bats have been investigated in histochemical studies (Vignoli, 1930; Maeir, 1965; Racey \& Tam, 1974; Gustafson, 1975a, b, 1976; Saidapur, 1976). In Pipistrellus pipistrellus (Type la pattern), the presence of $\Delta^{5}-3 \beta$ hydroxysteroid dehydrogenase (HSD) in Leydig cells was demonstrated with uniform intensity throughout the year (Racey \& Tam, 1974). However, the reaction for this enzyme was negative in the seminiferous tubules, even during spermatogenesis. Attempts to localize 17 $\beta$-HSD were unsuccessful. Furthermore, no discernible cycle of Leydig cell lipids could be found in this species during the year; small amounts of lipid were present in summer and winter. In Myotis $l$. lucifugus (Type Ib pattern), an intense reaction for $\Delta^{5}-3 \beta-H S D$ was observed in Leydig cells throughout the year, and in the seminiferous tubules, primarily in Sertoli cells, only during the summer spermatogenic period (Gustafson, 1975a, b, 1976). In contrast, weak 17 $\beta$-HSD activity was localized in Leydig cells and in the seminiferous tubules only during the spermatogenic period. In addition, a distinct cyclicity of Leydig cell lipids was observed. In May, following the bats' emergence from hibernation, sudanophilia of Leydig cells increased. During June there was a further increase which reached maximum intensity in late June. By late July, however, there 
was a dramatic decrease in stainable lipid droplets. A generally weak diffuse sudanophilia occurred during the remainder of the spermatogenic period until Leydig cell involution in September when an increase in stainable lipids occurred. This increase, which was not uniform throughout the perinuclear cytoplasm of the cells, mainly represents the accumulation of lipofuscin during this period as evidenced from the electron microscopic study cited earlier. During hibernation, there again appeared to be a slight increase in sudanophilia, possibly due to further autoxidative changes. However, at the end of this period and at the time of spring arousal, the small Leydig cells became weakly Sudan-positive (indicating loss of lipofuscin) while other cells that were large and numerously scattered throughout the interstitium were found with an intense sudanophilia. Based on light and electron microscopic criteria, these latter cells have been identified as macrophages which are charged with lipofuscin. It has been suggested that these cells, in anticipation of a new testicular cycle, may serve to remove from the Leydig cells the cytological residue that remains from the previous cycle (Gustafson, 1975a, 1976).

The presence of a histochemically detectable $\Delta^{5}-3 \beta-H S D$ throughout the year in Leydig cells of a bat with a Type Ib reproductive pattern is enigmatic, especially because Leydig cells in this species appear involuted during hibernation and lack a well defined SER, the organelle that is generally considered to be the cytological seat of this dehydrogenase (see Beyer \& Samuels, 1956; Tamaoki, 1973). However, an intramitochondrial localization of $\Delta^{5}-3 \beta$-HSD has been described in the rat testis (Sulimovici, Bartoov \& Lunenfeld, 1973). It is possible that such a localization also occurs in Myotis Leydig cells as mitochondria are abundant in these cells at all times of the year. The presence of $17 \beta$-HSD activity in Leydig cells during the period when the SER is well developed and its disappearance when the SER is lacking, however, is consistent with the view that this enzyme is microsomal (see Tamaoki, 1973).

The cycle of Leydig cell lipids in Myotis l. lucifugus, especially with regard to maximal lipid accumulation during the early phases of spermatogenesis and depletion during the latter part of this process before the mating season, is similar to lipid cycles that have been observed in other seasonally reproductive mammals (see review by Johnson, 1970). This cycle is also consistent with current cytophysiological concepts of Leydig cell function. Since the testis generally has a limited ability for the uptake of plasma cholesterol as compared to other steroid-secreting structures (see Eik-Nes, 1975), it has been suggested from studies in other mammals that the abundance of SER in Leydig cells reflects the degree to which cholesterol is synthesized within these cells (Christensen \& Gillim, 1969). Furthermore, following the synthesis of this sterol, it is rapidly esterified and accumulated in lipid droplets within the cytoplasm where these droplets then presumably serve as a pool of precursors for androgen synthesis (Christensen, 1975). Any decrease in the number of droplets may indicate their conversion to androgens. This is also apparently the case in Myotis l. lucifugus because as the lipid droplets disappear from Leydig cells in July, plasma testosterone levels rise (Gustafson \& Shemesh, 1976; see also below).

Using the Ciaccio method for lipids in a study that was apparently the first examination of changes in Leydig cell lipids during the year in a hibernating bat, Vignoli (1930) noted an annual cycle in Rhinolophus ferrumequinum (Type Ia pattern) that is surprisingly similar to the lipid cycle in Myotis l. lucifugus. The similarity of these two bats on this point is interesting, and raises the question of whether their reproductive patterns (see Table 2) are actually more similar than believed at present? Again, it is obvious that criteria other than solely histological ones must be used when examining bat reproductive cycles. These and similar problems invite further investigations.

Endocrine aspects. Few studies on male reproductive cycles in hibernating bats have sought to determine the endocrine activity of Leydig cells by more direct means (Racey, 1974; Racey \& Tam, 1974; Gustafson, 1976; Gustafson \& Shemesh, 1976). In Pipistrellus pipistrellus (Type Ia pattern), indicators of Leydig cell activity were sought during various times of the yearly cycle by measuring androgens in blood and testicular tissue, and by examining the conversions of pregnenolone to androstenedione and testosterone by testis slices in vitro (Racey \& Tam, 1974). 
Although blood testosterone was determined only at three intervals during the year, August $(80.5 \mathrm{ng} / \mathrm{ml})$, November $(119.8 \mathrm{ng} / \mathrm{ml})$ and February $(83.5 \mathrm{ng} / \mathrm{ml})$, these periods represent spermatogenesis, the beginning of hibernation and late hibernation respectively for this species. At first glance these exceptionally high blood testosterone levels suggest that Leydig cells may be active throughout most of the cycle, thereby confirming Courrier's (1927) observations. However, the low in-vitro conversion of pregnenolone to testosterone during November $(0.39 \%)$ and February $(9.74 \%)$ when compared to that at the beginning of the spermatogenic period (34.91\%) suggests that Leydig cells are most active during the spermatogenic period and are least active during hibernation, although possibly experiencing a rejuvenation during the second half of this period. Also, the higher percentages of androstenedione versus testosterone produced during hibernation $(3.27 \%$ in November and $33.17 \%$ in February) suggest that $17 \beta-\mathrm{HSD}$ is markedly less active or less abundant than $\Delta^{5}-3 \beta-$ HSD during this interval. This observation is consistent with the histochemical data. Furthermore, the greatly reduced content of testicular testosterone during February (12.7 ng/pair) than in August (125.3 ng/pair) also suggests low activity of Leydig cells during hibernation. These data, therefore, question the validity of Courrier's (1927) histological observations on this species and thus suggest further a closer similarity between the Leydig cell cycles of bats with the 'Pipistrellus' (Type Ia) and 'Myotis' (Type Ib) patterns.

As a measure of Leydig cell activity in the European noctule, Nyctalus noctula (Type Ia pattern), testicular and plasma testosterone levels were measured throughout the year in captive animals (Racey, 1974). Most of the population was caged and provided with food in an animal house ("open "lean-to'") that was exposed continuously to environmental conditions. Although bats became torpid in this facility during the cold months when they would normally have hibernated in their natural environment, they nevertheless aroused intermittently and fed. To control for these frequent arousals, a subgroup was removed from the animal house and placed in a cold room without available food during the winter. Under these conditions, the bats hibernated more or less continuously. The results of this study indicate that Leydig cells in this species are also most active during the spermatogenic period. For bats in the animal house, both testicular and plasma androgen levels were much lower during the colder months than during the spermatogenic period. Furthermore, for the cold room bats which experienced more or less continuously reduced body temperatures, hormone levels were even lower than those of their counterparts in the animal house. The cold-room conditions were probably more reflective of natural hibernating conditions, and so it appears that the plasma testosterone cycle in this species resembles that of Myotis l. lucifugus (see below) more closely than that of Pipistrellus pipistrellus. For this reason, perhaps the noctule should be classified as a 'Myotis pattern' bat or the 'Myotis' and 'Pipistrellus' patterns should be considered as being more similar.

Plasma testosterone levels have also measured in Myotis l. lucifugus (Type Ib pattern) in an effort to reflect Leydig cell activity (Gustafson, 1976; Gustafson \& Shemesh, 1976). Determinations of circulating androgen were made throughout the year from serially collected bats under natural conditions. Circulating testosterone levels were highest during the summer spermatogenic period and lowest during the hibernation period (see Text-fig. 1). Peak levels, occurring in August, corresponded to the hypertrophy of the accessory organs and a decrease in spermatogenic activity. Although the levels during hibernation are low for this species, they are similar to those observed in the majority of continuously reproductive mammalian species (Gustafson \& Shemesh, 1976). Taken alone, these data suggest that Leydig cell activity in Myotis l. lucifugus is greatest during the spermatogenic period and least during the hibernation period. However, the fine structural data for this species and the observation of Racey \& Tam (1974) that in-vitro testicular androgenesis is very low during hibernation in the pipistrelle, indicate that plasma testosterone levels during this period may not be a valid means of determining whether Leydig cell activity occurs at all. Indeed, reduced clearance rates or extratesticular 
androgen sources (see Krutzsch \& Wells, 1960) could account for the androgen levels at this time of general metabolic depression.

An interesting result from all of the above studies is the extremely high seasonal levels of circulating testosterone for hibernating bats. These levels are the highest known values for any mammalian species (Gustafson \& Shemesh, 1976).

Finally, the results of fine structural and endocrine evaluations of Leydig cell function to date, at least with regard to maximal Leydig cell activity, suggest that the apparent asynchrony between the exocrine and endocrine compartments of the testis in bats that hibernate is only apparent. Spermatogenesis and the thrust of Leydig cell function are not separated temporally, but rather are in close synchrony. Whether or not Leydig cells can be marginally active under normal conditions during hibernation, when a greatly reduced $17 \beta$-HSD activity is implied (Racey \& Tam, 1974) and when obvious steroidogenic machinery is lacking (Gustafson, 1975a), awaits further investigation.

\section{Accessory organs}

As noted earlier, maximal development of the accessory reproductive organs in bats that hibernate is achieved after spermatogenesis has terminated (see Table 1 and Text-fig. 1). Except for $M$. schreibersii (Type II pattern), this apparatus is maintained in secretory distention during the mating and hibernation periods (up to 9 months), suffering regressive collapse only after the bats' general arousal from hibernation in the spring (see Text-fig. 1). Considering the obligatory nature of androgen dependency for both spermatogenesis and the stimulation and maintenance of the accessory organs, these seasonal relationships suggest certain functional inconsistencies. Most studies of the assessment of annual changes in the accessory apparatus have been limited to gross morphological variations or descriptive histology. Although such analyses are logical first steps, the key to resolution of the apparent discrepancy of separate Leydig cell and accessory organ cycles would certainly seem to reside at the level of the secretory epithelia. In Myotis l. lucifugus, changes in the height of secretory epithelia vary in direct relation to plasma testosterone levels, with maximum height (hormonal stimulation) occurring in mid-August when peak plasma testosterone levels are measured and Leydig cells are still active (Gustafson, 1977), although maximum size of the accessory organs is observed in September when the Leydig cells have involuted. This lag between maximum epithelial size and full organ development is probably due to a gradual accumulation of stored luminal secretions as the synthetic efforts of the secretory epithelia are not utilized until mating begins, usually September for Myotis l. lucifugus. The reduction of epithelial cell size seen during the mating season and hibernation is probably due to lowered testosterone levels as well as glandular distension (Gustafson, 1977). Likewise, the decrease in overall size of the accessory organs after September (see Text-fig. 1) is probably due to utilization of secretory reserves during various mating efforts. In $M$. l. lucifugus, at least, there is therefore no asynchrony between Leydig cell function and maximum stimulation of the secretory epithelia.

\section{Neuroendocrine aspects of male cycles}

In studies on male reproductive periodicity in hibernating bats, almost no attention has been directed to changes in the hypothalamo-hypophysial portions of the brain-pituitary-gonad axis. Siegel (1965) reported that degranulation of basophils in the adenohypophysis of Myotis $l$. lucifugus occurs when males are aroused from hibernation. However, gonadotrophs were not examined at other times throughout the year. Herlant (1967) studied the effects of exogenous FSH on the seminiferous tubules in Myotis daubentoni and $M$. mystacinus during the second half of hibernation. A purified FSH preparation induced intense mitotic activity in spermatogonia as well as hypertrophy and lipid accumulation in Sertoli cells. Racey (1974) followed changes in 
pituitary weight throughout the year in Nyctalus noctula and found an increase during the second half of hibernation and an annual maximum in spring when the bats aroused from their winter torpor. Pituitary weight then decreased during the spermatogenic period, rose again when gametogenesis was terminated, and remained constant during the first half of hibernation. Brawer \& Gustafson (1978) have described the fine structural changes in tanycytes during the year in Myotis l. lucifugus. These specialized ependymal cells line the lower portion of the third ventricle and extend their cytoplasmic processes to the contact zone of the median eminence in the vicinity of the hypophysial portal vessels. It has been suggested that tanycytes have a role in the transport of LH-RH to the portal vessels from the CSF as well as from neurones in the arcuate nucleus (see Yen, Naftolin, Lein, Krieger \& Utiger, 1977). In this bat, tanycyte structure was unremarkable during the first half of hibernation following the cessation of spermatogenesis and involution of the Leydig cells, but during the second half striking changes were observed: fine filaments interspersed with microtubules increased in number, and the long attenuated processes of these cells formed multilamellar cytoplasmic sheaths that surrounded various neuronal elements. During the spermatogenic period, but especially in July and August when maximum levels of peripheral testosterone have been measured (see Text-fig. 1), tanycyte processes were characterized by hyperfilamentosis, dense accumulations of microtubules and further elaboration of multilamellar encapsulations around axons, dendrites and neuronal perikarya. These changes could represent the response of tanycytes to seasonal variations in neuroendocrine activity associated with male reproductive function. However, no causal relationships have yet been established.

In an effort to characterize by more direct means some neuroendocrine aspects which control male reproductive cycles in hibernating bats, work has been initiated to assess seasonal changes in plasma LH concentrations and basal brain LH-RH content in Myotis l. lucifugus. Preliminary data (unpublished) suggest that levels of $\mathrm{LH}$, the gonadotrophin involved in Leydig cell control, are highest in late May when bats resume activity following their general arousal from hibernation. These levels correspond to the beginning of spermatogenesis and the renewal of Leydig cell activity. Lowest levels were measured in late August following the testosterone surge that occurs in mid-August (see Text-fig. 1). Lowered levels also occurred during hibernation except in February and March when a transitory rise appeared.

At present, basal brain LH-RH content has been measured only in late summer and throughout hibernation. During these periods, minimum content was detected in February which represents the early part of the second half of hibernation. Both this depletion of the factor involved in gonadotrophin release and the rise in circulating LH observed at this time suggest a recent discharge of LH-RH. Therefore, from these data also it appears that a resurgence of neuroendocrine activity occurs during the second half of hibernation.

Thus, the available data on hypothalamo-hypophysial control of male reproductive cycles in hibernating bats suggest that neuroendocrine activity is greatest during the summer spermatogenic period and least during hibernation, especially during the first half. These data also suggest that a seasonal asynchrony in the release of pituitary gonadotrophins probably does not occur. However, the potential for renewal of testicular exocrine and endocrine activities may exist during the second part of hibernation, even though these activities are not normally manifest until bats resume their activity in the spring.

\section{Concluding remarks}

From the foregoing, it is evident that the sexual cycles of male bats that hibernate represent unusual mammalian patterns of reproductive periodicity. Recent investigations have begun to 
provide insights into some of their underlying physiological mechanisms. It is now evident, for example, that bats have an extremely high androgen requirement during the summer when spermatogenesis occurs and the accessory apparatus is renewed. However, this requirement is relatively much lower during mating and hibernation when secondary sexual functions (sperm storage, stimulated accessory organs and continued libido) are maintained. Nevertheless, the source of circulating androgens during hibernation is not yet clear. Reduced clearance rates could account for residual hormone levels, but this has not been investigated experimentally. Evidence that contributions to these levels from adrenal glands and brown fat can apparently be excluded is available for some 'Pipistrellus pattern' bats (Racey, 1974; Racey \& Tam, 1974). However, the possibility that brown fat may serve as an 'androgen pool' during hibernation, as suggested from the study on Myotis l. lucifugus by Krutzsch \& Wells (1960), has not been ruled out for any 'Myotis pattern' species. General body fat is abundantly accumulated before hibernation at about the time when elevated plasma testosterone levels occur and is then utilized slowly during hibernation, but any contribution that it might make to androgen storage and release during its mobilization requires examination. Wimsatt (1960) has suggested that the torpidity of hibernation alone may retard any regressive changes in the secondary sexual apparatus. This notion is supported by the fact that the accessory organs are maintained during hibernation when lowered androgen levels are circulating in the plasma, but quickly collapse in the face of similar levels when the bats resume normal activity in the spring (see Text-fig. 1). A further possibility that does not appear to have been considered is that regression of the accessory organs, a catabolically active process, may be an energetic luxury that bats cannot afford during hibernation. Certainly, many of the unique reproductive features of these bats are due to the intercalation of extended periods of dormancy into their annual cycles. However, whether hibernation alone is the explanation for the intrinsic endocrine phenomena remains to be fully determined. A reexamination of the cycle of European Miniopterus schreibersii with respect to controlling mechanisms is certainly essential. Nevertheless, excluding Miniopterus, this review can be concluded by summarizing male reproductive cycles in hibernating bats with a synthesis that may be generally true for the majority of species.

The spermatogenic process expresses itself only during the most favourable time of the year when bats are active and abundant insect food is available. Simultaneously, Leydig cells redifferentiate and regain functional form and activity in response to elevated levels of $\mathrm{LH}$. Shortly thereafter, the accessory organs, which have regressed to a prepubertal state in early summer, begin to respond to the renewed Leydig cell activity. Towards the end of summer, the secretory epithelia of these organs are maximally stimulated at the time of maximal plasma testosterone levels. These very high levels suggest an extreme stimulation of the accessory apparatus, which may be essential for the accumulation of abundant secretions before hibernation because the torpid status provoked by low temperature and depressed metabolic activity may not allow for continued renewal of these secretory products even if glandular epithelia are active. The elevated levels of testosterone in late summer also feed-back to the hypothalamo-hypophysial complex and inhibit gonadotrophic function, as evidenced by the depression of circulating $\mathrm{LH}$ levels and the internal disruption of Leydig cell organelles related to steroidogenesis. (Whether or not this deterioration occurs in 'Pipistrellus pattern' species remains to be determined.) Furthermore, these high androgen titres, through a brain-pituitary-Leydig cell-seminiferous tubule loop, may be responsible for the termination of spermatogenesis because these levels could serve as a natural spermatogenic suppressant much in the same way that exogenous androgen has been used experimentally in other mammals (see, for example, Steinberger \& Smith, 1977). When spermatogenic activity has ceased and Leydig cells have regressed, testosterone levels are reduced (except in Pipistrellus pipistrellus) but the accessory organs reach maximum gross size and the epididymides are replete with spermatozoa. This reproductive status signals the onset of mating. Various copulatory efforts draw on secretory and sperm reserves, effecting a measurable reduction in weight and volume of the accessory organs. However, as 
hibernation begins soon thereafter, the bats enter a profound torpor with accessory organs that are still enlarged by secretion and spermatozoa. Although copulations occur intermittently throughout the winter during periodic arousals, the secondary sexual apparatus is maintained until spring when it suffers abrupt regression shortly after the bats resume activity and a new testicular cycle begins.

In addition, during the first half of hibernation the bats seem to be refractory to renewed spermatogenic activity. This status is probably lost during the second half of this period, as indicated by a gradual increase in spermatogonial mitotic activity in hibernating animals, a rapid increase in tubular activity in artificially aroused animals, and an apparent renewal of neuroendocrine activity. However, neither Leydig cell renewal nor further tubular activity are normally manifest until spring when the bats emerge from their hibernacula. Yet, in the sense that a potential for testicular reawakening could exist during late hibernation, it is possible that bats may resemble other mammalian hibernators that actually do experience limited testicular renewal during this period (see Wimsatt, 1969). In the case of hibernating bats, however, the lack of insect food during this period and the more continuous nature of their torpid condition may prevent any renewed activity until resumption of higher body temperatures in spring. The possibility that renewed activity is energetically too expensive on a hibernating budget also cannot be overlooked. On the other hand, the level of the neuroendocrine stimulus during late hibernation as seen in Myotis l. lucifugus, may be below the required threshold for re-initiation of testicular activity, an interpretation that could be suggested by the much higher LH level that is apparently required when males resume normal activity in spring.

With regard to the effect of temperature on reproductive function in bats, the annual cycle of testicular activity in the bat Rhinopoma kinneari (Anand Kumar, 1965) in temperate India is of interest. In this species (Family Rhinopomatidae) the testes are permanently abdominal and the temporal separation of reproductive events that characterizes vespertilionid and rhinolophid bats does not occur. However, spermatogenesis takes place during the winter season although it is arrested during the warmer seasons. Although this bat is not a true hibernator, it does accumulate fat and apparently becomes torpid for periods in the colder winter months. It is possible that the combination of abdominal testicular location and periodic torpor during winter may provide a testicular temperature that is favourable for gametogenesis, whereas during warmer seasons the combination of the abdominal location and elevated body (and therefore testicular) temperatures may be unfavourable for this process as it is in cryptorchid animals. In any case, the testicond condition, and therefore higher testicular temperatures, may be required for optimal gonadotrophic responses and normal spermatogenesis when this animal experiences intermittent torpidity.

This work was supported in part by Sigma Xi Grants in Aid of Research and the Charlton Fund of Tufts University. I am indebted to Dr W. Duane Belt for his helpful comments and criticism of this review, and to Ms D. Hemenway and Ms B. White for typing the manuscript.

\section{References}

Anand Kumar, T.C. (1965) Reproduction in the rat tailed bat Rhinopoma kinneari. J. Zool., Lond. 147, 147-155.

Belt, W.D. \& Pease, D.C. (1956) Mitochondrial structure in sites of steroid secretion. J. Biophys. Biochem. Cytol., Suppl. 2, 369-374.

Benecke, B. (1879) Ueber Refung und Befruchtung des Eies bei den Fledermäusen. Zool. Anz. 2, 304-305.

Beyer, K.F. \& Samuels, L.T. (1956) Distribution of steroid-3 $\beta$-ol-dehydrogenase in cellular structures of the adrenal gland. J. biol. Chem. 219, 69-76.
Branca, A. (1904) Sur la glande urétrale des Rhinolophes. C.r. Ass. Anat. 6, 175.

Brawer, J.R. \& Gustafson, A.W. (1978) Seasonal variations in the fine structure of ependymal tanycytes in the male little brown bat Myotis lucifugus lucifugus. Anat. Rec. 190, 346.

Christensen, A.K. (1975) Leydig cells. In Handbook of Physiology, Sect. 7, Vol. V, pp. 57-94. Eds R. O. Greep \& D. W. Hamilton. Am. Physiol. Soc., Washington, D.C.

Christensen, A.K. \& Gillim, S.W. (1969) The correlation 
of fine structure and function in steroid-secreting cells, with emphasis on those of the gonads. In The Gonads, pp. 415-488. Ed. K. W. McKerns. Appleton-Century-Crofts, New York.

Christian, J.J. (1956) The natural history of a summer aggregation of the big brown bat, Eptesicus fuscus fuscus. Am. Midl. Nat. 55, 66-95.

Courrier, R. (1920) Sur l'existence d'une sécrétion épididymaire chez la chauve-souris hibernante et sa signification. C. r. Séanc. Soc. Biol. 83, 67-69.

Courrier, R. (1923a) Cycle annuel de la glande in terstitielle du testicule chez les Chéiroptères. Coexistence du repos séminal et de l'activité génitale. $C$. r. Séanc. Soc. Biol. 88, 1163-1166.

Courrier, R. (1923b) Sur le cycle de la glande inter stitielle et l'évolution des caractères sexuels secondaires chez les mammiféres à spermatogénèse périodique. C. r. Séanc. Soc. Biol. 89, 1311-1313.

Courrier, R. (1926a) Les effets de la castration chez les Chëiroptères. C. r. Séanc. Soc. Biol. 94, 1386-1388.

Courrier, R. (1926b) Un cas d'eunuchoidisme avec spermatogenèse normale chez une pipistrelle. $C$. $r$. Ass. Anat. 21, 176-182.

Courrier, R. (1927) Etude sur le déterminisme des caractères sexuels secondaires chez quelques mammifères à activité testiculaire périodique. Archs Biol. 37, 173-334.

Duval, M. (1895a) Études sur l'embryologie des Chéiroptères. J. Anat. Physiol., Paris 31,93-160.

Duval, M. (1895b) Sur l'accouplement des chauvessouris. C. r. Séanc. Soc. Biol. 47, 135-136.

Dwyer, P.D. (1963a) Reproduction and distribution in Miniopterus (Chiroptera). Aust. J. Sci. 25, 435-436.

Dwyer, P.D. (1963b) The breeding biology of Miniopterus schreibersi blepotis (Temminck) (Chiroptera) in north-eastern New South Wales. Aust. J. Zool. 11, 219-240.

Eik-Nes, K.B. (1975) Biosynthesis and secretion of testicular steroids. In Handbook of Physiology, Sect. 7, Vol. V, pp. 95-115. Eds R. O. Greep \& D. W. Hamilton. Am. Physiol. Soc., Washington, D.C.

Eimer, T. (1879) Ueber die Fortpflanzung der Fledermäuse. Zool. Anz. 2, 425-426.

Fries, S. (1879) Ueber die Fortpflanzung der einheimischen Chiropteren. Zool. Anz. 2, 355-357.

Gaisler, J. (1966) Reproduction in the lesser horseshoe bat (Rhinolophus hipposideros hipposideros Bechstein, 1800). Bijdr. Dierk. 36, 45-64.

Gaisler, J. \& Titlbach, M. (1964) The male sexual cycle in the lesser horseshoe bat (Rhinolophus hipposideros hipposideros Bechstein, 1800). Věst. čsl. Spol. zool. 28, 268-277.

Gustafson, A.W. (1975a) A study of the annual male reproductive cycle in a hibernating vespertilionid bat (Myotis lucifugus lucifugus) with emphasis on the structure and function of the interstitial cells of Leydig. Ph.D. thesis, Cornell University, Ithaca, New York.

Gustafson, A.W. (1975b) Observations on the hydroxysteroid dehydrogenase and lipid histochemistry and ultrastructure of the Leydig cells in adult Myotis l. lucifugus (Chiroptera: Vespertilionidae) during the annual reproductive cycle. Anat. Rec. 181, 366367.
Gustafson, A.W. (1976) A study of the annual male reproductive cycle in a hibernating vespertilionid bat (Myotis lucifugus lucifugus) with emphasis on the structure and function of the interstitial cells of Leydig. Diss. Abstr. B 36, 4792-4793.

Gustafson, A.W. (1977) Observations on the male accessory apparatus in the hibernating vespertilionid bat Myotis lucifugus lucifugus during the annual reproductive cycle. Anat. Rec. $\mathbf{1 8 7}, 595$.

Gustafson, A.W. \& Shemesh, M. (1976) Changes in plasma testosterone levels during the annual reproductive cycle of the hibernating bat Myotis lucifugus lucifugus with a survey of plasma testosterone levels in adult male vertebrates. Biol. Reprod. 15, 9-24.

Herlant, M. (1967) Action de la gonadotropine FSH sur le tube séminifère de la Chauve-Souris hibernante. $C$. r. hebd. Séanc. Acad. Sci., Paris D 264, 2483-2486.

Johnson, A.D. (1970) Testicular lipids. In The Testis, Vol. Il, pp. 193-258. Eds A. D. Johnson, W. R. Gomes \& N. L. VanDemark. Academic Press, New York.

Jordan, H.E. (1912) Notes on the spermatogenesis of the bat. Anat. Anz. 40, 513-522.

Koceva, V. (1970) Prilog proucavanju sezonskog ritma seminika kod slepog misa (ljiljaka) (Myotis oxygnatus). God. Zb. Med. Fak. Skopje. 16, 361371.

Krutzsch, P.H. (1961) The reproductive cycle in the male vespertilionid bat Myotis velifer. Anat. Rec. 139, 309.

Krutzsch, P.H. (1975) Reproduction of the canyon bat, Pipistrellus hesperus, in southwestern United States. Am. J. Anat. 143, 163-200.

Krutzsch, P.H. (1979) Male reproductive patterns in nonhibernating bats. J. Reprod. Fert. 56, 333-344.

Krutzsch, P.H. \& Wells, W.W. (1960) Androgenic activity in the interscapular brown adipose tissue of the male hibernating bat (Myotis lucifugus). Proc. Soc. exp. Biol. Med. 105, 578-581.

Kunz, T.H. (1973) Population studies of the cave bat (Myotis velifer): reproduction, growth, and development. Occ. Pap. Mus. nat. Hist. Univ. Kans. No. 15, $1-43$.

Maeir, D.M. (1965) Species variation in testicular $\Delta^{5}-3 \beta$ hydroxysteroid dehydrogenase activity: absence of activity in primate Leydig cells. Endocrinology 76, 463-469.

Mein, P. \& Tupinier, Y. (1977) Formule dentaire et position systematique du Minioptère (Mammalia, Chiroptera). Mammalia 41, 207-211.

Miller, R.E. (1939) The reproductive cycle in male bats of the species Myotis lucifugus lucifugus and Myotis grisescens. J. Morph. 64, 267-295.

Nakano, O. (1928) Über die Verteilung des Glykogens bei den zyklischen Veränderungen in den Geschlechtsorganen der Fledermaus. Und über die Nahrungsaufnahme der Spermien in dem weiblichen Geschlechtswege. Folia anat. jap. 6, 777-828.

Neaves, W.B. (1975) Leydig cells. Contraception 11, 571-606.

Neaves, W.B. (1977) Leydig cells. In Frontiers in Reproduction and Fertility Control, Part 2, pp. 321-337. Eds R. O. Greep \& M. A. Koblinsky. The MIT Press, Cambridge, Massachusetts. 
Oh, Y.K. (1977) Periodic changes of the testis and ductus epididymis in Korean hibernating bats. Korean J. Zool. 20, 67-76.

Oxberry, B.A. (1979) Female reproductive patterns in hibernating bats. J. Reprod. Fert. 56, 359-367.

Pearson, O.P., Koford, M.R. \& Pearson, A.K. (1952) Reproduction of the lump-nosed bat (Corynorhinus rafinesquei) in California. J. Mammal. 33, 273-320.

Phillips, G.L. (1966) Ecology of the big brown bat (Chiroptera:Vespertilionidae) in northeastern Kansas. Am. Midl. Nat. 75, 168-198.

Racey, P.A. (1974) The reproductive cycle in male noctule bats, Nyctalus noctula. J. Reprod. Fert. 41, 169-182.

Racey, P.A. (1979) The prolonged storage and survival of spermatozoa in Chiroptera. J. Reprod. Fert. 56, $391-402$.

Racey, P.A. \& Tam, W.H. (1974) Reproduction in male Pipistrellus pipistrellus (Mammalia:Chiroptera). J. Zool., Lond. 172, 101-122.

Rauther, M. (1903) Bemerkungen über den Genitalapparat und die Analdrüsen der Chiropteren. Anat. Anz. 23, 508-524.

Retterer, E. \& Neuville, H. (1913) Du gland et du prépuce de quelques Cheiroptères. C.r. Séanc. Soc. Biol. 75, 381-383.

Rice, D.W. (1957) Life history and ecology of Myotis austroriparius in Florida. J. Mammal. 38, 15-32.

Richardson, E.G. (1977) The biology and evolution of the reproductive cycle of Miniopterus schreibersii and $M$. australis (Chiroptera:Vespertilionidae). $J$. Zool., Lond. 183, 353-375.

Robin, H.A. (1881) Recherches anatomiques sur les Mammifères de l'ordre des Chiroptères. Annls Sci. nat., Zool. Biol. anim. 12, 1-180.

Rollinat, R. \& Trouessart, E. (1895a) Sur la reproduction des chauves-souris. Bull. Soc. zool. Fr. 20, 2528.

Rollinat, R. \& Trouessart, E. (1895b) Sur la reproduction des Chiroptères. C. r. Séanc. Soc. Biol. 47, 53-54.

Rollinat, R. \& Trouessart, E. (1895c) Deuxième note sur la reproduction des Chiroptères. C. r. Séanc. Soc. Biol. 47, 534-536.

Rollinat, R. \& Trouessart, E. (1896) Sur la reproduction des chauves-souris. Le Vespertilion murin (Vespertilio murinus Schreber). Mém. Soc. zool. Fr. 9, 214240.

Rollinat, R. \& Trouessart, E. (1897) Sur la reproduction des chauves-souris. II. Les Rhinolophes, et note sur leurs parasites épizoïques. Mém. Soc. zool. Fr. 10, 114-138.
Saidapur, S.K. (1976) Histochemical localization of $\Delta^{5}$. $3 \beta-, 17 \beta$-, and $11 \beta$-hydroxysteroid dehydrogenases and glucose-6-phosphate dehydrogenase activities in the testis of bat, Vesperugo pipistrellus (Dobson). Curr. Sci. 45, 729-730.

Schoenfeld, H. (1904) La spermatogenèse chez la noctule (Vesperugo noctula). Annls Bull. Soc. r. Med. Gand. 84, 141-159.

Siegel, J.H. (1955) Cytochemical and histophysiological observations on the basophils of the anterior pituitary gland of the bat, Myotis lucifugus lucifugus. J. Morph. 96, 223-264.

Sluiter, J.W. (1961) Sexual maturity in males of the bat Myotis myotis. Proc. K. ned. Akad. Wet., Ser. C 64, 243-249.

Stebbings, R.E. (1966) A population study of bats of the genus Plecotus. J. Zool., Lond. 150, 53-75.

Steinberger, E. \& Smith, K.D. (1977) Effect of chronic administration of testosterone enanthate on sperm production and plasma testosterone, folliclestimulating hormone, and luteinizing hormone levels: a preliminary evaluation of a possible male contraceptive. Fert. Steril. 28, 1320-1328.

Sulimovici, S., Bartoov, B. \& Lunenfeld, B. (1973) Localization of $3 \beta$-hydroxysteroid dehydrogenase in the inner membrane subfraction of rat testis mitochondria. Biochim. biophys. Acta 321, 27-40.

Tamaoki, B. (1973) Steroidogenesis and cell structure. Biochemical pursuit of sites of steroid biosynthesis. $J$. Steroid Biochem. 4, 89-118.

Van Beneden, E. (1880) Contribution a la connaissance de l'ovaire des mammifères. L'ovaire du Vespertilio murinus et du Rhinolophus ferrum-equinum. Archs Biol. 1, 475-550.

Vignoli, L. (1930) Il testicolo di Rhinolophus ferrum equinum nella sua maturazione sessuale e nelle sue variazioni cicliche annuali. Archs ital. A nat. Embriol. 28, 103-132.

Vogt, C. (1881) Recherches sur l'embryogénie des chauves-souris (Chiroptères). C. r. Ass. fr. Avanc. Sci. 10, 655-663.

Wimsatt, W.A. (1960) Some problems of reproduction in relation to hibernation in bats. Bull. Mus. comp. Zool. Harv. 124, 249-267.

Wimsatt, W.A. (1969) Some interrelations of reproduction and hibernation in mammals. Symp. Soc. exp. Biol. 23, 511-549.

Yen, S.S.C., Naftolin, F., Lein, A., Krieger, D. \& Utiger, R. (1977) Hypothalamic influences on pituitary function in humans. In Frontiers in Reproduction and Fertility Control, Part 2, pp. 108-127. Eds R. O. Greep \& M. A. Koblinsky. The MIT Press, Cambridge, Massachusetts. 